Review

\title{
Cultivar Identification of Rice (Oryza sativa L.) by PCR Method and its Application to Processed Rice Products
}

\author{
(Received February 19, 2007; Accepted May 14, 2007) \\ Ken' ichi Ohtsubo $^{1, *}$ and Sumiko Nakamura ${ }^{1}$ \\ ${ }^{1}$ National Food Research Institute (2-1-12, Kannondai, Tsukuba 305-8642, Japan)
}

\begin{abstract}
As the cultivars of rice affect markedly eating quality, processing suitability and price, identification or differentiation of rice cultivars is very important. The present authors developed suitable STS (sequencetagged-site) primers for PCR (Polymerase Chain Reaction) and it became possible to identify rice cultivars using template DNA extracted and purified from rice grains. A multiplex primer set was shown to be useful to differentiate effectively rice cultivars produced in various countries by PCR. Two kinds of multiplex kit for identification of Koshihikari, the dominant cultivar in Japan, have been developed. The application of the cultivar identification method by PCR to processed rice products was investigated. The present authors developed an "enzyme treatment method," in which the gelatinized starch is decomposed by the heat-stable $\alpha$ amylase at $80^{\circ} \mathrm{C}$, followed by hydrolysis of proteins by proteinase $\mathrm{K}$ with SDS and purification of extracted DNAs by PCI (Phenol/Chloroform/iso-amyl alcohol). It became possible to identify the material rice cultivars of the processed rice products, such as cooked rice and rice cake, by the PCR method using template DNA prepared by the "enzyme treatment method."
\end{abstract}

Key words: rice, DNA, cultivar identification, PCR, processed rice product

Rice is one of the most important edible crops in the world, along with wheat and corn. There are more than several tens of thousands of varieties or cultivars of rice in the world. Rice is markedly diversified from the viewpoint of genetics, morphology and properties. On the other hand, high-quality rice is closely related by inbreeding to attain high-palatability, high processing suitability, characteristic aroma, etc.

Rice grains of the famous cultivars are traded or distributed at higher prices as "premium rice" than the ordinary rice because of their high palatability, processing suitability, special aroma, etc. As those premium rice grains sell at high price, some dishonest rice wholesalers or retailers blend low quality cheap rice with high quality premium rice and mislabel it as "high-quality premium rice." Recently, rice consumers have tended to demand more information, such as cultivar name, location of production, year of production, etc., about rice which they purchase. For example, it is required under the JAS LAW (Law Concerning Standardization and Proper Labeling of Agricultural and Forestry Products in Japan) to display the name of rice cultivar on the package. Therefore, technology to identify rice cultivars is very important for breeders, farmers, inspectors, wholesalers, retailers, food industries and consumers.

\footnotetext{
${ }^{*}$ Corresponding author (Tel. +81-29-838-8012, Fax. +81-29-8387996, E-mail: kenohtsu@affrc.go.jp).

Abbreviations: STS, sequence-tagged-site; PCR, polymerase chain reaction; CTAB, cetyl tri-methyl ammonium bromide; PCI, phenol/chloroform/iso-amyl alcohol; JAS LAW, law concerning standardization and proper labeling of agricultural and forestry products in Japan; SCAR, sequence characterized amplified region; RAPD, random amplified polymorphic DNA.
}

Rice cultivars have been identified on the basis of morphological characteristics of rice plants or grains, ripening ratio after crossing, isozyme patterns, etc. Cultivated rice (Oryza sativa L.) is one of the most polymorphic crop species in the world. In contrast, many cultivars of highquality rice or premium rice are closely related because inbred lines are often used for their development. Therefore, it is necessary to develop a time-saving technology to differentiate rice cultivars clearly and precisely.

DNA fingerprinting was developed in $1985^{1)}$ and is used for criminal investigation and trial at court. Recently, a novel cultivar identification method based on DNA polymorphism has been developed accompanied with the progress in molecular biology. DNA-based markers have the obvious advantage of sampling the genome directly and RFLP analysis has been widely used for assessing variation of plants. ${ }^{2-4)}$ RFLP analysis has been used to distinguish between species of Oryza ${ }^{5)}$ and particularly between indica and japonica types of Oryza sativa. ${ }^{6}$

Recently, a PCR-based marker system has been developed by Williams et al. .7) In this RAPD (Random Amplified Polymorphic DNA) method, short oligo-nucleotides of arbitrary sequences are used to support the amplification of regions of the test plant genome and amplified DNAs are separated by gel electrophoresis.

There are some reports on RAPD analysis of rice germplasm including indica and japonica types, to identify suitable parents for linkage map construction, and for gene tagging for drought resistance. ${ }^{8,9)}$ RAPD analysis was revealed to be reproducible and amenable for identification of each single plant line of F1 hybrid rice in China ${ }^{10)}$ and Australian rice cultivars. ${ }^{11)}$ Diversified rice cultivars were classified into separate groups by PCR using RAPD markers, but many primers were needed to resolve closely 
related japonica cultivars. ${ }^{12-14)}$

In the case of RAPD markers, many other DNA bands than the target DNA for cultivar differentiation appear in the electrophoregram after PCR. Therefore, it is recommended to develop STS (sequence tagged site) markers or SCAR (sequence characterized amplified region) markers based on RAPD markers.

In addition to RAPD markers, microsatellites or simple sequence repeats (SSRs), which are DNA sequences with repeat lengths of a few base pairs and variation in the number of nucleotide repeats, can be detected with PCR by selecting the conserved DNA sequences flanking the SSR as primers. In 1993, SSR markers were developed for rice. ${ }^{15,16)}$ SSR markers are useful not only to characterize the relationship between heterosis and marker genotype heterozygosity but also to identify chromosome segments that may have significant effects on yield and its component traits in rice. ${ }^{17}$

Genetic diversity among Indian elite rice varieties was evaluated using three different types of DNA markers and parentage analysis. ${ }^{18)}$ SSLP was reported to be more reliable than AFLP for identifying rice cultivars. ${ }^{19)}$ RAPD, RFLP, nuclear SSLP and chloroplast SSLP analyses were carried out to clarify the phylogenetic relationships among A-genome species of rice. ${ }^{20)}$ SSR was reported to provide useful genetic information on weedy rice. ${ }^{21)}$

Development of a genome-wide DNA polymorphism database for map-based cloning of rice genes was investigated using SNP markers. ${ }^{22)}$ SNPs were also used for the discussion on the sequence variations between the rice cultivars. ${ }^{23)}$

Although SSR and SNPs are very useful DNA markers, it is impossible to use several PCR primers, or "multiplex PCR," simultaneously to simplify the PCR and electrophoresis and save time. Furthermore, no report has claimed to identify or differentiate the material rice cultivars by PCR method using the processed rice products, such as boiled rice or rice cakes.

The present authors have investigated cultivar identification of rice by the PCR method. ${ }^{24-28)}$

In the present study, application of PCR technology to cultivar identification of rice grains was investigated. SCAR markers and multiplex primer sets were developed based on RAPD marker analyses to differentiate closely related rice cultivars clearly and efficiently by PCR.

An efficient method to prepare the template DNA for PCR from the processed rice products, such as cooked rice or rice cakes, was investigated. The identification or the differentiation of material rice cultivars by multiplex PCR was carried out using processed rice products as samples.

\section{MATERIALS AND METHODS}

Materials. Fifteen various kinds of rices were collected or purchased. Sample rice grains used are as follows; Koganemochi (Japan), Hinohikari (Japan), Akitakomachi (Japan), Kirara397 (Japan), Ilpum (Korea), Calmochi101 (USA), Medium grain (USA), Forbidden rice (USA), Pelde (Australia), Kyeema (Australia), Paellea (USA), Long grain (USA), Doongara (Australia), Nanjing
11 (China), IR2061 (Philippines).

Thirty three original Koshihikari rice seeds, produced in 1999, 2000 and 2001, were used for DNA extraction and purification. All the rice samples including 49 other cultivar rice samples besides Koshihikari were kindly provided by National Food Agency, Japan. The 49 cultivars are Hitomebore, Hinohikari, Akitakomachi, Kirara397, Kinuhikari, Hoshinoyume, Haenuki, Mutsuhomare, Niopponbare, Sasanishiki, Tsugaruroman, Hanaechizen, Yumetsukushi, Hatsushimo, Asanohikari, Tsukinohikari, Aichinokaori, Matsuribare, Akiho, Yukimaru, Mutsukaori, Manamusume, Kakehashi, Kiyonishiki, Domannaka, Koshijiwase, Yukinosei, Hohohonoho, Yumeakari, Notohikari, Akitsuho, Akebono, Asahi, Yamahoushi, Yamahikari, Koganenishiki, Koganemasari, Reiho, Mineasahi, Fusaotome, Karinomai, Dontokoi, Akinishiki, Naganohomare, Fukuhikari, Goropikari, Hatsuboshi, Nakateshinsenbon and Morinokumasan.

Paddy rice samples were hulled by an experimental huller (Ketto Science Laboratory, Tokyo) and milled to the yield of $90 \%$ by an experimental rice polisher (Pearlest, Ketto Science Laboratory, Tokyo). Milled rice flours were prepared by a coffee mill (Millser IFM-100, Iwatani, Tokyo).

Physical and chemical properties of the 20 rice cultivars. Amylose contents were measured by the iodinecolorimetric method using the milled rice flours by the method of Juliano. ${ }^{29)}$ Protein contents were calculated by the multiplication of nitrogen-protein conversion coefficient ( 5.95 for rice) to the nitrogen contents measured by the Kjeldahl method. ${ }^{30)}$ Physical properties of the boiled rice grains were measured by the method of Okadome ${ }^{31)}$ using a Tensipresser.

Preparation of boiled rice and rice cake. White rice prepared by the experimental rice polisher (Ketto Science Laboratory) was boiled in an electric rice cooker (RC183, Toshiba, Tokyo) after soaking for $1 \mathrm{~h}$ and each single boiled rice grain was subjected to the extraction of template DNA for PCR.

Milled waxy rice was pulverized using an experimental impact mill (Udy Cyclone Mill, Udy Corporation, Fort Collins, USA). Thirty-five grams of water was added to $50 \mathrm{~g}$ of the rice powder and kneaded manually. A rice cake was prepared using an electric rice cake maker for home use (SMK-1800, Tiger Co., Ltd., Tokyo). The rice cake was lyophilized and pulverized using a coffee-mill (IFM-100) and subjected to DNA extraction.

Extraction and purification of template DNA from milled rice flours. According to the CTAB method, ${ }^{32,33)}$ DNAs of the milled rice flours were extracted. Milled rice flours $(0.4 \mathrm{~g})$ were placed in the micro-centrifugal tube $(2$ $\mathrm{mL}$ ) and DNAs were extracted into the $0.6 \mathrm{~mL}$ of $2 \times$ CTAB (Cetyl trimethylammonium bromide, 2\% CTAB, $20 \mathrm{~mm}$ EDTA ( ethylenediamine- $N, N, N^{\prime}, N^{\prime}$-tetraacetic acid), $1.4 \mathrm{M} \mathrm{NaCl}, 0.1 \mathrm{M}$ tris-hydroxyl aminomethane/ $\mathrm{HCl}$ buffer, $\mathrm{pH} 8.0$ ) solution and $0.2 \mathrm{~mL}$ distilled water for $30 \mathrm{~min}$ at $65^{\circ} \mathrm{C}$. The solution of chloroform and isoamyl alcohol $(24: 1, \mathrm{v} / \mathrm{v})(0.8 \mathrm{~mL})$ was added and stirred gently for $15 \mathrm{~min}$ using a rotator. Thereafter, the solution was centrifuged $(8000 \times g, 15 \mathrm{~min})$ in a refrigerated centrifuge (hi-mac CR21F, Hitachi, Hitachi) and the upper 
layer was transferred to another micro-tube. CTAB solution $(10 \%, 0.08 \mathrm{~mL})$ and chloroform/isoamyl alcohol $(24$ : $1, \mathrm{v} / \mathrm{v})$ were added to the solution and it was stirred gently for $15 \mathrm{~min}$ followed by centrifugation $(8000 \times g, 15$ min). The upper layer was transferred to another tube and was stood for $5 \mathrm{~min}$ in the freezer $\left(-80^{\circ} \mathrm{C}\right)$ after the addition of 2.5 volumes of the precipitation buffer $(50 \mathrm{mM}$ Tris-HCl, $\mathrm{pH}$ 8.0, $10 \mathrm{~mm}$ EDTA, 1\% CTAB). The precipitate was collected by the centrifugation $(6000 \times g, 15$ min) and dissolved in the $0.5 \mathrm{~mL}$ of Tris-EDTA buffer (TE) and was added with the same volume of isopropyl alcohol. After the gentle stirring by a rotater for $15 \mathrm{~min}$, the precipitate was collected by the centrifugation $(6000 \times$ $g, 15 \mathrm{~min}$ ). The precipitate was dissolved in $0.2 \mathrm{~mL}$ of TE followed by the decomposition of RNAs by the addition of $1 \mu \mathrm{L}$ of RNase (RNase A, bovine pancreas, 10 $\mathrm{mg} / \mathrm{mL}$, Nippon-gene Inc., Tokyo) and incubation for $1 \mathrm{~h}$ at $55^{\circ} \mathrm{C}$. Thereafter, neutral phenol solution was added and the upper layer was transferred to another tube after the centrifugation $(8000 \times g, 15 \mathrm{~min})$. The same volume of the solution of phenol/chloroform $(1: 1, \mathrm{v} / \mathrm{v})$ was added to the solution followed by the centrifugation $(8000 \times g, 15$ min) and the upper layer was transferred to another tube. The solution was supplemented with $0.2 \mathrm{M} \mathrm{NaCl}$ and two volumes of cold ethanol to generate the precipitate of DNAs. The DNAs were washed by the $50 \mu \mathrm{L}$ of $70 \%$ ethyl alcohol and dissolved in $30 \mu \mathrm{L}$ of $0.1 \mathrm{TE}$ and were subjected to PCR.

Preparation of DNA in case of processed rice products. In the case of processed rice products, such as boiled rice grains or rice cakes, a different DNA extraction/purification method was developed. ${ }^{25,26)}$ The processed rice product, such as a cooked rice grain, was subjected to the decomposition of starch by heat-stable $\alpha$ amylase $(790 \mathrm{U} / \mathrm{mg}$ solid, $30 \mathrm{mg} / \mathrm{mL}$, from Bacillus licheniformis, Sigma, USA) for $60 \mathrm{~min}$ at $80^{\circ} \mathrm{C}$. For the starch digestion, $20 \mu \mathrm{L}$ of above-mentioned $\alpha$-amylase $(\mathrm{mg} / \mathrm{mL})$ was added to the $1.5 \mathrm{~mL}$ of the sample solution ( $0.1 \mathrm{~g}$ of single boiled rice grain in the solution of $50 \mathrm{~mm}$ Tris-HCL buffer, $\mathrm{pH}$ 8.0) and digestion was performed for $1 \mathrm{~h}$ at $80^{\circ} \mathrm{C}$. Thereafter, the protein hydrolysis was carried out by proteinase K (Takara-bio Inc., Otsu, Japan) For the protein digestion, $10 \mu \mathrm{L}$ of proteinase $\mathrm{K}$ solution $(27.7 \mathrm{u} / \mathrm{mg}, 20 \mathrm{mg} / \mathrm{mL})$ was added to the starch-digested solution with $1 \%$ of sodium-dodecylsulphate (SDS). The protein digestion was carried out for $1 \mathrm{~h}$ at $55^{\circ} \mathrm{C}$. Thereafter, DNAs were extracted by the same amount of TrisEDTA saturated phenol solution and purified by the phenol/chloroform/iso-amyl alcohol (PCI, 25/24/1, v/v/v) and $70 \%$ ethyl alcohol. For the control, a commercial DNA extraction kit (Isoplant, Nippongene, Tokyo) was used.

Polymerase chain reaction (PCR). DNAs were proliferated by the PCR method using 600 commercial random primers (10 mers or 12 mers) as primers. ${ }^{24}$ Taq-DNA polymerase (Takara-bio Inc., Otsu, Japan) was used for amplification of DNAs. Each DNA was denatured for 1 min at $94^{\circ} \mathrm{C}$, annealed for $1 \mathrm{~min}$ at $62^{\circ} \mathrm{C}$ and elongated for $2 \mathrm{~min}$ at $72^{\circ} \mathrm{C}$. This procedure was repeated 40 times. As a PCR apparatus, Thermal Cycler MP (Takara-bio Inc., Otsu, Japan) was adopted.
Electrophoreses of the amplified DNAs. Proliferated DNAs were subjected to electrophoresis for $30 \mathrm{~min}$ through agarose gel (2\%) using a Mupid-2 electrophoresis system (Advance, Tokyo, Japan) at the charge of $100 \mathrm{~V}$ of direct current. After the electrophoresis, the DNAs were stained with ethydium bromide and detected by the irradiation of UV light.

Development of SCAR markers and multiplex primer sets. In the present study, SCAR markers were developed based on RAPD analysis to differentiate rice cultivars by PCR. ${ }^{25-28)}$ DNAs were extracted from the agarose gel after the electrophoresis of the PCR products using Easy $\operatorname{trap}^{\mathrm{TM}}$ (Takara-bio Inc., Otsu, Japan). DNA cloning was carried out using a TOPO XL PCR Cloning $\mathrm{Kit}^{\mathrm{TM}}$ (Invitrogen Corporation, Carlsbad, USA). DNA sequence was determined using a commercial DNA preparation kit (QIAprep Spin Miniprep kit, Qiagen, K.K., Tokyo) and DNA proliferation kit (Big Dye Terminator Cycle sequencing kit, V1-1, Applied Biosystems Japan, Tokyo) and automatic DNA sequencing system (DNA sequencer ABI PRISM Genetic Analyzer 310, Applied Biosystems Japan, Tokyo). SCAR markers were designed based on the DNA sequences with from 20 mers to 29 mers so that the transition temperatures are around $62^{\circ} \mathrm{C}$. The combinations of these SCAR markers, the "multiplex primer sets," were developed to identify Koshihikari, the most dominant rice cultivar in Japan.

\section{RESULTS}

\section{Development of SCAR markers.}

An example of the development of SCAR markers for identification or differentiation of rice cultivars is shown in Table 1. The sequence of the differential DNA, which was extracted from the electrophoresis agarose gel after PCR of the RAPD method, was determined and the suitable forward and reverse primers, about 20 mers, were designated as shown in Table $1 .^{27,28)}$

The electrophoregrams after PCR using RAPD marker, B43, and SCAR marker, B43, are shown in Fig. 1. Compared with the RAPD marker, the SCAR marker is more useful because only the differential DNA is amplified, which makes it easy and accurate to differentiate the rice cultivar.

Developed SCAR markers for identification or differentiation of rice cultivars are shown in Table 2.

\section{Physicochemical properties of rice samples.}

Various rice samples were collected from different districts in the world and their chemical and physical properties were measured. ${ }^{28)}$ The results are shown in Table 3. As shown in Table 3, Indica subspecies, such as IR2061 and Nanjing 11, showed high amylose content and less adhesiveness; in contrast, Japonica sub-species, such as Hinohikari and Akitakomachi, revealed low amylose content and more adhesiveness.

\section{Application of PCR to various rice samples.}

The CTAB method can be applied to milled rice flour for extraction and purification of template DNA for $\mathrm{PCR}^{32-34)}$ The result of PCR using 15 rice cultivars from 
Table 1. Sequence of DNA amplified by the use of primer B43.

\begin{tabular}{rlr}
1 & TGGCCGGCATGACTCACATACCCAACATATAGCATATCTGGATGTCTGTT & 50 \\
51 & TGCAATCATGTCGGGTGATCGAGCCAACAACGTTTGCGAGGAATTTATCC & 100 \\
101 & GTTAACGACATATTCTCCAATAGTTCGGACATGGCCGGCGCTATACATGA & 150 \\
151 & GATAAGTCGTCAGTCTTCATTGGTAGGTTGGGTGCGACAACTCAGCCTTT & 200 \\
201 & ATCGAGAATGTTCTTGACAATGGGGTGTACTCGACCACAACCTACTCGAG & 250 \\
251 & TGCTCAATTGTTCCTGAAAAATATTTTCTAGAAGACAAGATATATAGCAG & 300 \\
301 & ATAGTATCGAGCATATACTCAAAAGACTGCATGAATCTTCTATTATTATC & 350 \\
351 & ATGATATAACGAACAGATTAAATATCATACATTATGTAAACCATAAGTAA & 400 \\
401 & GCATGATTTATACATAAGAAAATAAAGCGAGCCCCCAGTATTAAACCGTT & 450 \\
451 & GTTGACCTAATATAGGGAATGCTCACACAATAGATATTGTATAGAAAACA & 500 \\
501 & TGCTCTAGGTAAACATAATAAATTTGAAATCTGACAATATCGTATTTATC & 550 \\
551 & TGAAGAATAGGTACGATAAATCACATATAAAATATTGCGTAGCTTTGTAG & 600 \\
601 & ATACATGTAGGATGTATCTACGAACGAAATTAGTAGGTCAACTTAAAAAA & 650 \\
651 & TTAATCTACTAATTACCTTTCTGACATGTGTATTCGGAGTAGATTAGATC & 700 \\
701 & GATGCAATCATACTTCTCCAAGTGGACAGCCGCATGTATGCAGTAAACAC & 750 \\
751 & ATGCACTTGCTGTTAATTGATCTCATGCATGCACATATTGACGTCATCCA & 800 \\
801 & AATTGGTTGGTCTTGATGCCGGCCAGT & 837 \\
\hline
\end{tabular}

Underlined sequences were used as primers for PCR.

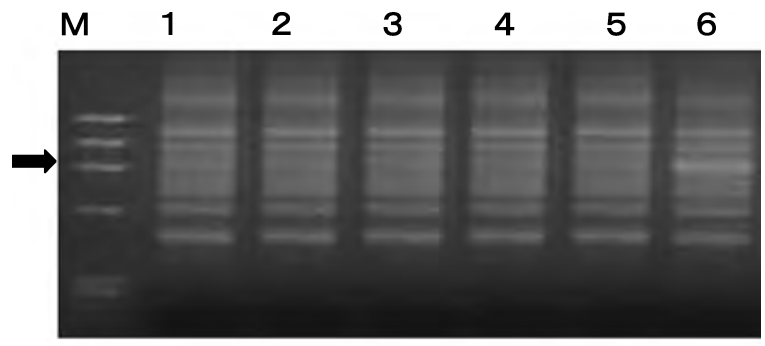

(a)

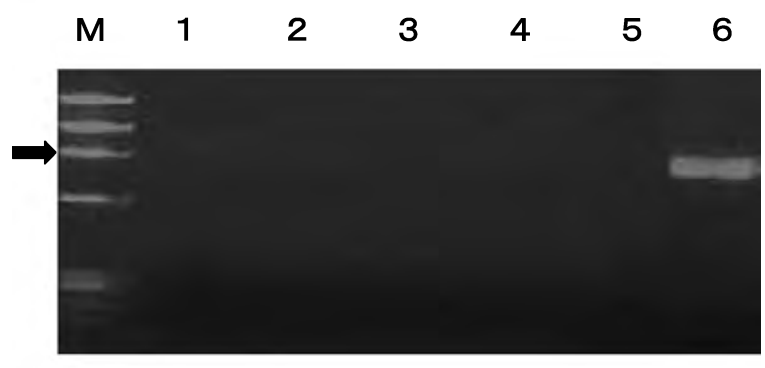

(b)

Fig. 1. Comparison of RAPD and SCAR markers in PCR and electrophoresis.

M, DNA molecular weight markers (Marker 4, Wako Purechemical Co., Ltd.); 1, Hinohikari; 2, Haenuki; 3, Kinuhikari; 4, Akitakomachi; 5, Kirara397; 6, Koshihikari. Arrow, differential DNA. (a) RAPD marker (B43, Operon Co., Ltd.), (b) SCAR marker (B43 in Table 1).

various countries, such as the USA, India, Thailand or Japan, as samples is shown in Fig. 2. The primer set used for PCR was our commercial Koshihikari Positive Kit (Takara-bio Inc.). Four DNA bands appeared clearly in the case of Hitomebore and three appeared clearly in the case of Koshihikari, which were revealed to be useful to differentiate various rice cultivars by a single time PCR and electrophoresis.

\section{Primer set for Koshihikari identification.}

As shown in Fig. 3, Koshihikari can be discriminated from any other cultivars using this "primer set for identification" making three specific DNA bands. ${ }^{27)}$ There is no other cultivar rice which shows the same three-band pat-
Table 2. Sequences of SCAR markers.

\begin{tabular}{lcl}
\hline Primer & F/R & \multicolumn{1}{c}{ Sequences } \\
\hline B1 & F & GTTTCGCTCCTACAGTAATTAAGGG \\
& R & GTTTCGCTCCCATGCAATCT \\
B7 & F & CAGGTGTGGGTTACAAGGATGA \\
& R & CAGGTGTGGGTTCACGGCCTTT \\
B43 & F & TGGCCGGCATGACTCAC \\
& R & ACTGGCCGGCATCAAGAC \\
B43a & F & TGGCCGGCATGACTCACA \\
& R & ACTGGCCGGCATCAAGA \\
E30 & F & TACCTGGTTGATGTATACAGATCTGGTT \\
& R & ATCCCTCGATCCCTCTAGCATTAT \\
F6 & F & ACCACTCCATATATATCATCCAAAG \\
& R & ACCACTCCATATCACCACAAGG \\
G22 & F & CTCACTCAAATTTACAGTGCATTTCTTG \\
& R & AGGGCCATGATACAAGACTCTGT \\
M2CG & F & ACAACGCCTCCGATGA \\
& R & ACAACGCCTCCGACAACAAGAT \\
M11 & F & GTCCACTGTGACCACAACAT \\
& R & GTCCACTGTGGGGATTGTTC \\
S13 & F & GTCGTTCCTGTGGTTAGGACAGGGT \\
& R & GTCGTTCCTGCTGGTGTCTCAGAT \\
Wka9 & F & CCCGCAGTTAGATGCACCATT \\
& R & CCGCAGTTAGATCAAGTGGC
\end{tabular}

F, forward; $R$, reverse.

Table 3. Proximate components and physical properties of various cultivar rice.

\begin{tabular}{|c|c|c|c|c|}
\hline \multirow{3}{*}{$\begin{array}{r}\text { Cultivar } \\
\text { Koganemochi }\end{array}$} & \multirow{3}{*}{$\begin{array}{c}\text { Amylose } \\
(\%)\end{array}$} & \multirow{3}{*}{$\begin{array}{c}\text { Protein } \\
(\%)\end{array}$} & \multirow{2}{*}{\multicolumn{2}{|c|}{$\begin{array}{c}\text { Physical properties } \\
\text { Adhesion Consistency }\end{array}$}} \\
\hline & & & & \\
\hline & & & 2.12 & 15 \\
\hline Hinohikari & 16.3 & 5.6 & 1.65 & 92 \\
\hline Akitakomachi & 18.0 & 5.3 & 1.32 & 116 \\
\hline Kirara397 & 19.9 & 6.5 & 1.54 & 106 \\
\hline Ilpum & 16.9 & 5.9 & 1.07 & 104 \\
\hline Calmochi101 & 0.9 & 5.6 & 2.00 & 44 \\
\hline Medium grain & 17.6 & 6.1 & 0.68 & 125 \\
\hline Forbidden rice & 17.1 & 7.4 & 0.58 & 127 \\
\hline Pelde & 18.6 & 7.2 & 0.39 & 110 \\
\hline Kyeema & 18.9 & 7.8 & 0.59 & 143 \\
\hline Paellea & 20.4 & 6.9 & 0.51 & 139 \\
\hline Long grain & 15.4 & 7.0 & 0.31 & 207 \\
\hline Doongara & 24.7 & 8.8 & 0.32 & 185 \\
\hline Nanjing11 & 27.8 & 11.0 & 0.19 & 190 \\
\hline IR2061-214 & 32.0 & 9.0 & 0.11 & 180 \\
\hline
\end{tabular}

Adhesion was measured by a Tensipresser and the unit is $\mathrm{mm}$. Consistency was measured by a Rapid Visco Analyser and the unit is RVU. 
tern as Koshihikari among 50 dominant non-glutinous rice cultivars in Japan (Fig. 3A). On the other hand, all Koshihikaris of the different prefectures showed the same DNA patterns (Fig. 3B).

\section{Primer set for differentiation of other rice with Koshi-} hikari.

As shown in Fig. 4, no DNA is proliferated in the case
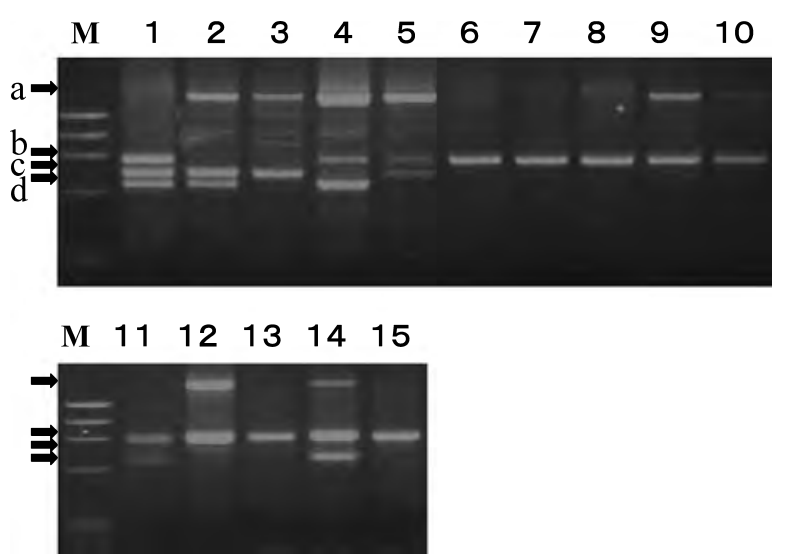

Fig. 2. Example of the PCR using the primer set for the differentiation of various kinds of rice cultivars.

1, Koganemochi; 2, Hinohikari; 3, Akitakomachi; 4, Kirara397; 5, Ilpum; 6, Calmochi101; 7, Medium grain; 8, Forbidden rice; 9, Pelde; 10, Kyeema; 11, Paellea; 12, Long grain; 13, Doongara; 14, Nanjin11; 15, IR2061. Marker a, Wka9; b, B43; c, M11; d, G22.

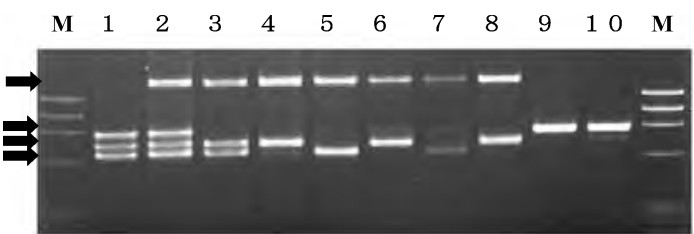

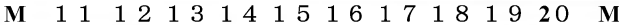
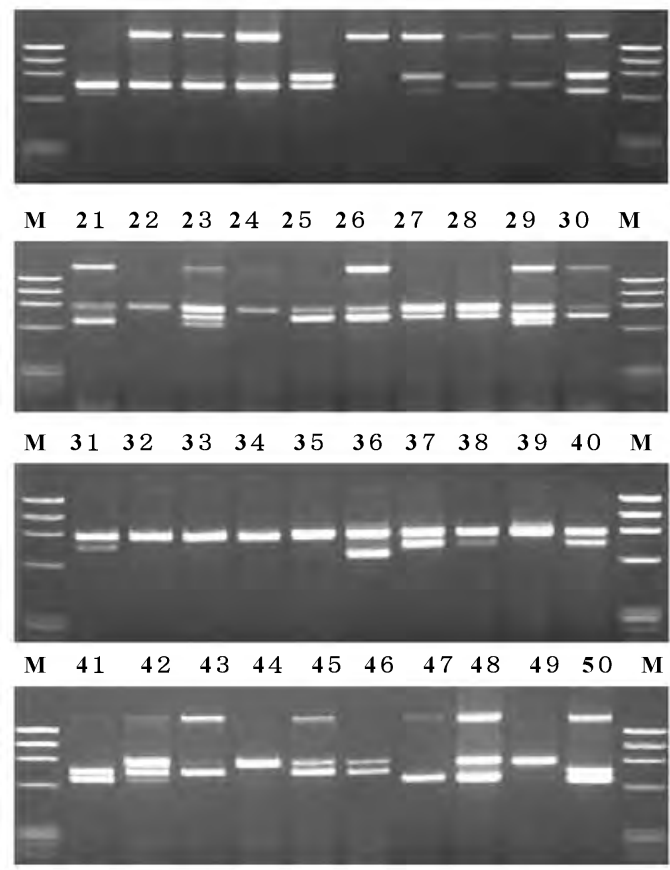

A of all Koshihikari rice grains of various prefectures (Fig. 4B), and multiple DNA bands never fail to increase by PCR in the case of rice grains of other cultivars (Fig. 4A). ${ }^{27)}$

\section{Novel DNA extraction/purification method from pro- cessed rice products.}

Comparison of template DNAs prepared by the three methods, the commercial kit method, the CTAB method and the "enzyme treatment method," was carried out. ${ }^{25)}$ The quantity and quality of the template DNAs are shown in Table 4 and Fig. 5. The "enzyme treatment method" was shown to be profitable from the viewpoint of quality and quantity.

\section{Differentiation of material rice cultivars of boiled rice by $P C R$.}

In the case of boiled white rice grains, as shown in Fig. 6, it became possible to differentiate Hitomebore or Hinohikari from Koshihikari, their parental cultivar by PCR using the template DNA prepared from each single grain of boiled rice by the "enzyme treatment method," which was described in MATERIALS AND METHODS. ${ }^{25)}$

\section{Differentiation of material rice cultivars of rice cake} by PCR.

The results of PCR using template DNAs prepared from each rice cake by the "enzyme treatment method"
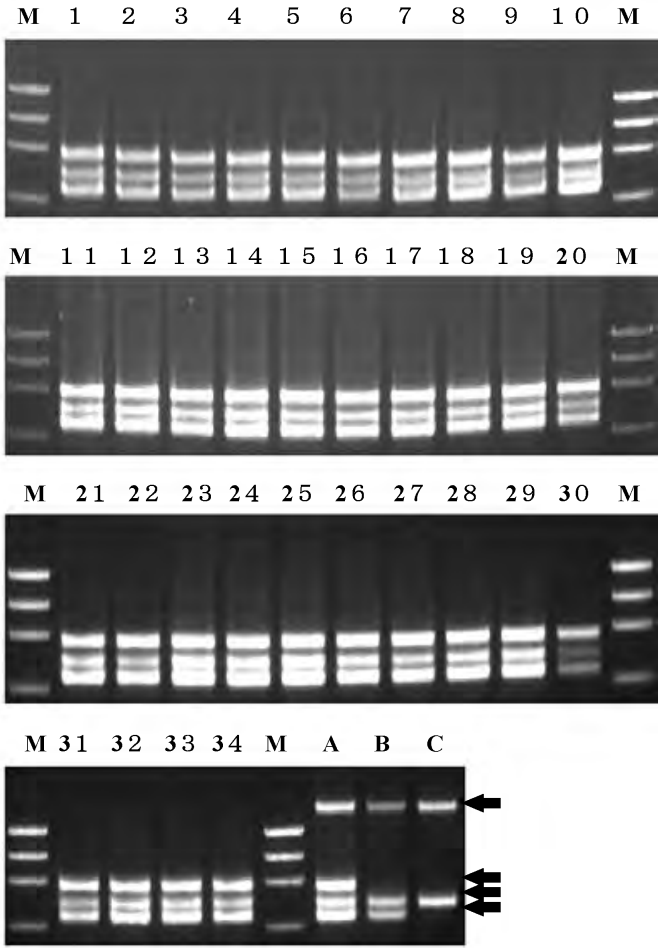

$\mathrm{B}$

Fig. 3. Primer set for identification of Koshihikari.

(A) Comparison of DNA patterns between Koshihikari and other rice cultivars. No. 1, Koshihikari; Nos. 2-50, Other cultivars. (B) Results of Koshihikaris of different prefectures. A, Hitomebore; B, Hinohikari; C, Akitakomachi. Used primers are Wka9, B43, M11 and G22. 

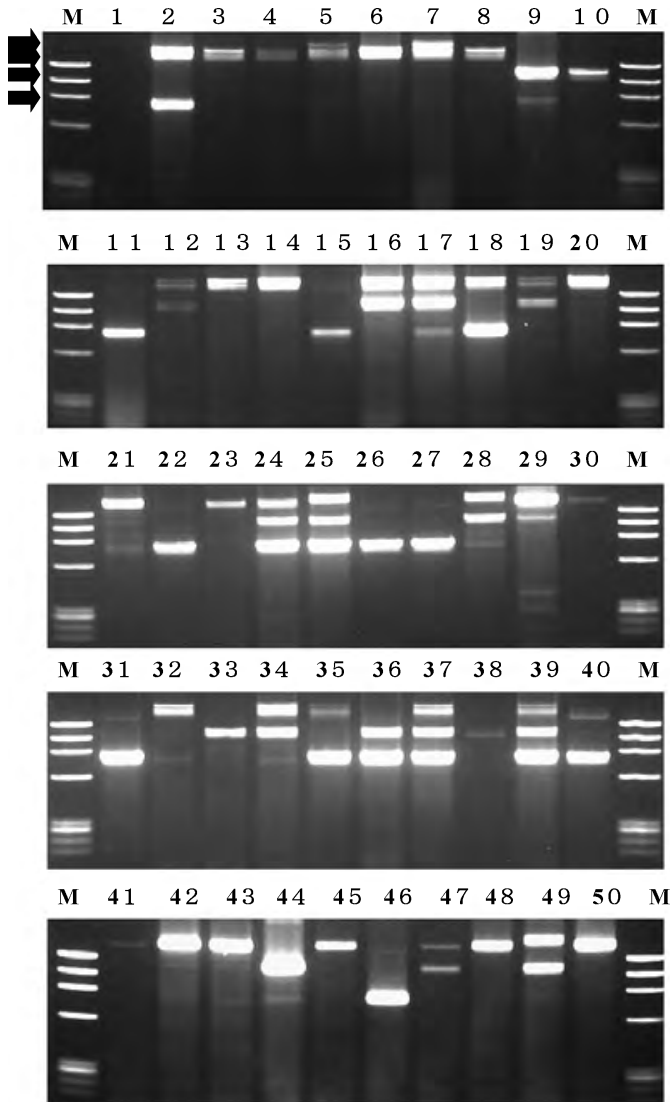

A

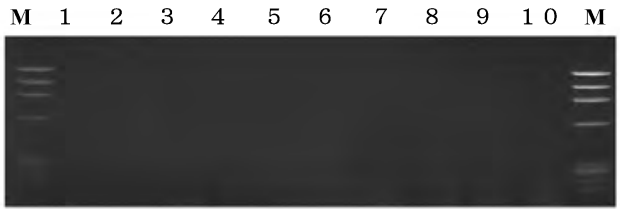

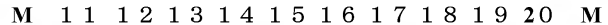
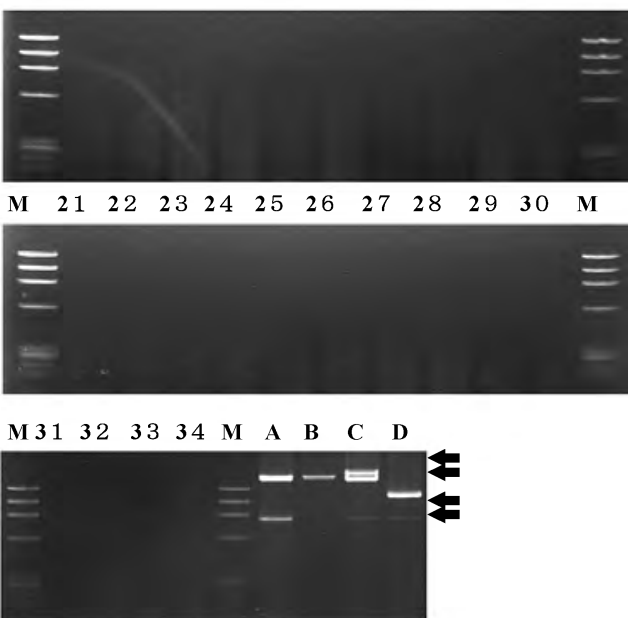

Fig. 4. Primer set for detection of other cultivar rice grains from Koshihikari.

(A) Comparison of DNA patterns between Koshihikari and other rice cultivars. No.1, Koshihikari (No DNA is proliferated by PCR.); Nos. 2-50, Other cultivars (DNA band appears with PCR). (B) Results of Koshihikaris of different prefectures. A, Hitomebore; B, Hinohikari; C, Kirara397; D, Mutsuhomare; Used primers are Wka9, S13, F6 and E30.

Table 4. DNA extraction by the different methods.

\begin{tabular}{|c|c|c|c|c|c|c|}
\hline \multirow[b]{2}{*}{ Cultivar } & \multicolumn{2}{|c|}{ Enzyme method } & \multicolumn{2}{|c|}{ CTAB method } & \multicolumn{2}{|c|}{ Commercial kit (Isoplant) } \\
\hline & $\begin{array}{c}\text { Extracted DNA } \\
(\mu g)\end{array}$ & OD260/OD280 & $\begin{array}{c}\text { Extracted DNA } \\
(\mu g)\end{array}$ & OD260/OD280 & $\begin{array}{c}\text { Extracted DNA } \\
(\mu \mathrm{g})\end{array}$ & OD260/OD280 \\
\hline Koshihikari & 9.89 & 1.84 & 3.10 & 1.95 & 7.08 & 2.06 \\
\hline Hitomebore & 8.67 & 1.80 & 1.97 & 1.97 & 11.88 & 2.01 \\
\hline Akitakomachi & 11.63 & 1.94 & 3.79 & 2.17 & 10.31 & 2.10 \\
\hline Sasanishiki & 10.70 & 1.84 & 3.69 & 2.03 & 9.18 & 2.10 \\
\hline Nipponbare & 14.04 & 1.88 & 4.96 & 1.89 & 8.03 & 1.99 \\
\hline Hinohikari & 11.50 & 1.76 & 3.68 & 2.17 & 8.57 & 2.06 \\
\hline Yukihikari & 9.80 & 2.02 & 4.25 & 2.12 & 9.65 & 1.74 \\
\hline Kirara397 & 16.70 & 1.88 & 5.27 & 2.09 & 10.31 & 2.10 \\
\hline Mutsuhomare & 11.57 & 1.97 & 4.20 & 2.17 & 7.94 & 2.20 \\
\hline Kinuhikari & 8.46 & 1.73 & 2.96 & 2.05 & 9.15 & 2.10 \\
\hline Average & 11.30 & 1.87 & 3.81 & 2.06 & 9.21 & 2.06 \\
\hline $\mathrm{SD}$ & 2.38 & & 0.95 & & 1.33 & \\
\hline
\end{tabular}

were same as those using template DNAs from material rice flour directly by the CTAB method, as shown in Fig. $7{ }^{26)}$

\section{DISCUSSION}

\section{Properties of rice grains of various rice cultivars.}

In the case of trade contract, inspection or grading or the survey of traceability of rice grains, the PCR method must be applied using rice grains as samples. Shoots or leaves are not available as sample specimens. Therefore, milled rice flour, a single kernel of polished rice or even boiled rice is used as materials for PCR in the postharvest inspection.

Rice is markedly diversified from the viewpoint of genetics, morphology and properties. On the other hand, high-quality rice is closely related by inbreeding to attain high-palatability, high processing suitability, characteristic aroma, etc.

Rice grains of the famous cultivars are traded or distributed at higher prices as "Premium rice" because of their high palatability, processing suitability, special aroma, etc. ${ }^{34,35)}$

In the present study, various rice samples were col- 


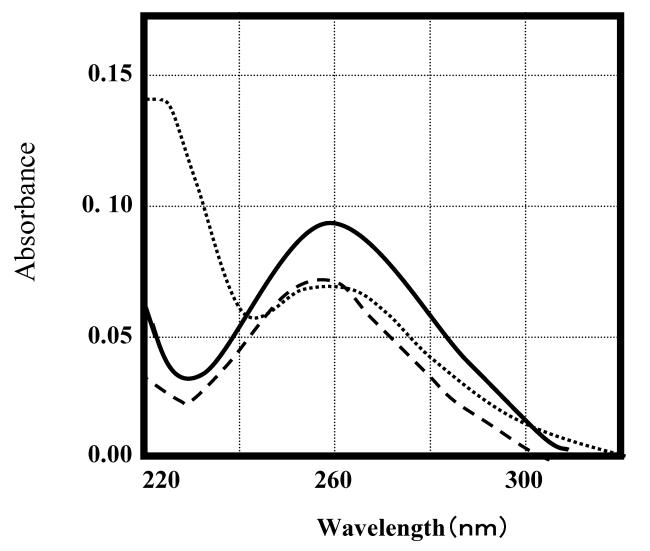

Fig. 5. Ultra-violet absorbance spectra of DNAs prepared by the different methods.

Enzyme method; -----, CTAB method;

kit method.

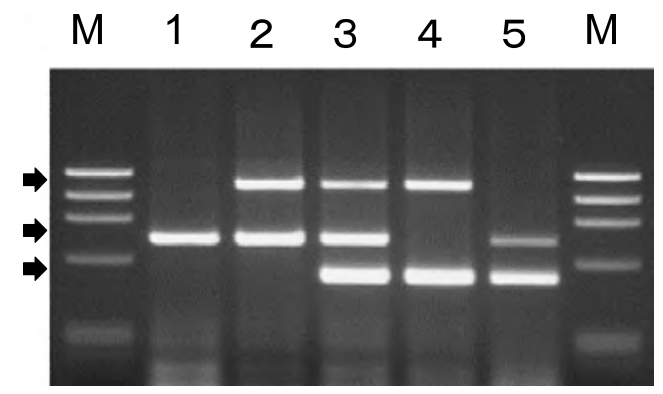

Fig. 6. Differentiation of Japanese rice cultivars by PCR using template DNA extracted from a single boiled rice grain by the "enzyme treatment method."

Arrows, DNAs proliferated by PCR; 1, Koshihikari; 2, Hitomebore; 3, Hinohikari; 4, Mutsuhomare; 5, Kinuhikari. Used primers are M2CG, M11 and B7.

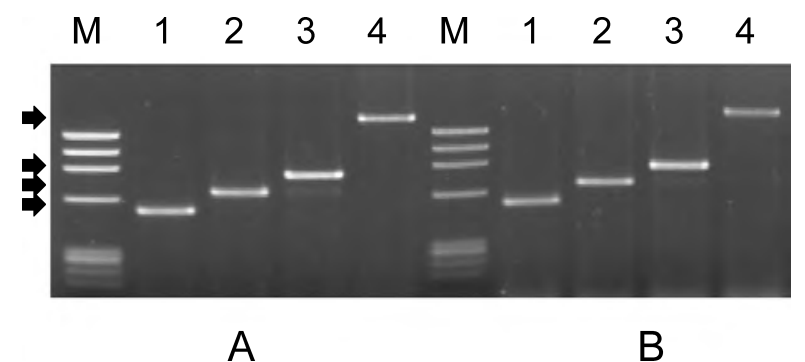

Fig. 7. Differentiation of Japanese rice cultivars by PCR using template DNA extracted from the raw rice flours or the rice cake by the use of "enzyme treatment method."

M, DNA molecular weight marker; 1, Hiyokumochi; 2, Koganemochi; 3, Hakuchomochi; 4, Wataboushi. (A) Template DNAs were prepared from milled rice flours, (B) template DNAs were prepared from rice cake. Used primers are Wka9, E30, G22 and $\mathrm{B} 1$.

lected from different district around the world and their chemical and physical properties were measured. As shown in Table 3, the grain properties between Indica subspecies, such as IR2061, and Japonica sub-species, such as Hinohikari, were revealed to be very different, but those among the same sub-species are not different.

\section{Development of SCAR markers.}

As shown in Table 1 and Fig. 1, SCAR markers are more useful than RAPD markers ${ }^{27,28,34,35)}$ because they are clearer in electrophoregrams. Furthermore, it is possible to use several SCAR markers simultaneously in PCR, which leads to saving time and labor. As shown in Table 2, several kinds of SCAR markers were developed. The length of markers was adjusted so that the transition temperatures of the markers are around the same temperature, $62^{\circ} \mathrm{C}$. Therefore, several SCAR markers can be used simultaneously in "multiplex PCR."

\section{Multiplex primer set, Koshihikari positive kit.}

As shown in Fig. 2, the multiplex primer set for PCR, Koshihikari Positive Kit, is very useful to differentiate various rice cultivars from the different districts in the world. It was shown that RAPD analysis is a useful tool in determining the genetic relationships among rice cultivars. $^{9-14)}$ Nevertheless, it is necessary to perform many PCRs and electrophoreses to distinguish rice cultivars by RAPD or SSR markers because those markers are difficult to use simultaneously in the same experiment. It became possible to save experiment time and cost by the use of multiplex primer sets based on SCAR markers.

Figure 2 is an example of how the multiplex SCAR marker set is useful to differentiate various rice cultivars by a single PCR and electrophoresis. Three DNA bands appeared clearly in the case of Koganemochi, a premium Japonica waxy rice, and three others appeared clearly in the case of Hinohikari, a premium non-glutinous Japonica rice. In the case of Nanjing 11, a typical Indica nonglutinous rice, three different bands appeared, which are useful to differentiate it from the other Indica rice, IR2061.

\section{Multiplex primer set, "Detection kit of mislabeling."}

In Japan, leading variety Koshihikari shares more than one third of the total cultivation area of rice because it is palatable and traded at a higher price than other rice cultivars. It is required, in Japan, that the name of the rice cultivar, location of cultivation, and year of rice production are labeled on the package of rice by the Japan Agricultural Standard (JAS) Act. Therefore, it was necessary to develop the technology to identify the Koshihikari cultivar by DNA analysis.

As shown in Fig. 3A, Koshihikari can be discriminated from any other cultivars using this "primer set for identification" showing three specific DNA bands. ${ }^{27)}$ There is no other cultivar rice which shows the same three-band pattern as Koshihikari among 50 dominant non-glutinous rice cultivars in Japan. All the Koshihikari from the different districts showed the same pattern of three DNA bands, which correspond to the same grouping under Japanese Seeds and Seedling Law based on representative characteristics of rice plants (Fig. 3B). On the other hand, no cultivars other than Koshihikari showed the same DNA patterns as Koshihikari, not even Hitomebore or Hinohikari, which are descendant cultivars of Koshihikari, as shown in Fig. 3. ${ }^{27)}$

As the premium rice Koshihikari sells at a high price, mislabeling "Koshihikari 100\%" occurs with dishonest rice retailers in Japan. For the purpose of detection of rice grains of other cultivars which were dishonestly blended into Koshihikari, a detection-kit was developed. In the 
case of the detection-kit, no DNA is proliferated in the case of any Koshihikari rice grains of any prefecture (Fig. 4B), and multiple DNA bands never fail to increase by $\mathrm{PCR}$ in the case of rice grains of other cultivars (Fig. 4A). This "primer set for detection" can be used to detect the illegal blending of other rice with Koshihikari labeled as "Koshihikari $100 \%$ premium rice." 27$)$

SSR markers are useful not only to characterize the relationship between heterosis and marker genotype heterozygosity but also to identify chromosome segments that may have significant effects on yield and its component traits in rice. ${ }^{15-20)}$ SNPs were used for the discussion on the sequence variations between the rice cultivars. ${ }^{22,23)}$ Nevertheless, "multiplex primer sets" using SCAR markers were revealed to be more useful and practical for efficient and precise cultivar differentiation.

\section{"Enzyme treatment method" for preparation of tem-} plate DNA from processed rice products.

In the case of boiled white rice grains, gelatinized rice starch and heat-denatured proteins inhibit the extraction of DNA. Therefore, it is necessary to remove these starches and proteins without the damage or decomposition of the DNAs themselves. The high temperature of $80^{\circ} \mathrm{C}$ during the starch decomposition by the heat-stable $\alpha$-amylase and coexistence of SDS during the protein digestion are meaningful to inhibit the activity of endogenous DNase.

Although a commercial DNA extraction kit is very useful to prepare the template DNAs from rice leaves, it is not suitable for boiled rice as shown in Fig. 5. No amplified DNA bands appeared after PCR in the case of template DNA prepared by the commercial kit. ${ }^{25)}$ In the case of the CTAB method, it is possible to prepare purified DNAs, but it was inferior to the "enzyme treatment method" in terms of the quantity of DNAs, as shown in Table $4 .{ }^{25)}$

Lysozyme is sometimes used for DNA preparation. ${ }^{36)}$ But lysozyme decomposes cell walls mainly, and it is difficult to digest the gelatinized starch and denatured proteins with it.

It became possible to proliferate specific DNAs by PCR using template DNA prepared by the "enzyme treatment method" and the multiplex primer set is very useful to differentiate various rice cultivars by a single PCR and electrophoresis, as shown in Fig. 6. ${ }^{25}$

\section{Multiplex PCR for identification of material rice of rice cakes.}

The "enzyme treatment method" is also useful for preparation of template DNAs from rice cakes. The solubility of rice cakes in boiling water and expansion on heating varies depending on the cultivar and production area of the material glutinous rice. ${ }^{37)}$ Therefore, identification of cultivars of the material glutinous rice using rice cakes as samples is very important. The results of PCR using template DNAs prepared from each rice cake by the "enzyme treatment method" were same as those using template DNAs from material raw rice flour directly by the CTAB method, as shown in Fig. 7. It became possible to differentiate each material waxy rice cultivar by a single PCR and electrophoresis by the development of a primer set for "multiplex PCR" to identify waxy rice cultivars. $^{26)}$

\section{Meaning of the development of scar markers for mul- tiplex primer sets and the "enzyme treatment method" for DNA preparation from the processed rice prod- ucts.}

In conclusion, it became possible to identify or differentiate rice cultivars by PCR. A practical primer set for Koshihikari, the dominant cultivar in Japan, was developed. It became possible to identify or differentiate the dominant cultivar by a single PCR without timeconsuming RAPD analysis or elaborate electrophoresis for SSR analysis. Furthermore, the results were same as those based on the plant characteristics. ${ }^{27,35)}$

It became possible to use not only raw rice grains but also processed rice products, such as boiled rice or rice cakes, as materials for cultivar identification by the PCR method by the development of the "enzyme treatment method." The interference of DNA extraction by the gelatinized starch and denatured proteins of the processed rice products is removed by the decomposition of starch and proteins. Heat-stable $\alpha$-amylase was very useful because the high temperature of $80^{\circ} \mathrm{C}$ inhibits the DNase activities during the starch decomposition and SDS is useful to prohibit the DNase during the protein digestion. ${ }^{25)} \mathrm{A}$ single boiled rice grain or rice cake can be used as a sample for identification or differentiation of material rice cultivars by the PCR method. ${ }^{25,26)}$

A part of this research was supported by a Grant-in-Aid (Development of evaluation and management methods for supply of safe, reliable and functional food and farm produce) from the Ministry of Agriculture, Forestry and Fisheries of Japan.

The present authors express gratitude to Dr. Shinji Kawasaki and Mr. Takeshi Fujii for their valuable advice and cooperation.

\section{REFERENCES}

1 ) A.J. Jeffreys, A. MacLeod, K. Tamaki, D.L. Neil and D.G. Monckton: Minisatellite repeat coding as a digital approach to DNA typing. Nature, 316, 76-79 (1985).

2 ) P.S. Virk, B.V. Ford-Lloyd, M.T. Jackson and H.J. Newbury: Use of RAPD for the study of diversity within plant germplasm collections. Heredity, 74, 170-179 (1995).

3 ) T. Helentjaris, G. King, M. Slocum, C. Siedenstrang and S. Wegman: Restriction fragment polymorphism as probes for plant diversity and their development as tools for applied plant breeding. Plant Mol. Biol., 5, 109-118 (1985).

4 ) S.D. Tanksley, N.D. Young, A.H. Paterson and M.W. Bonierbale: RFLP mapping in plant breeding: new tools for an old science. Bio/Technol., 7, 258-264 (1989).

5 ) Z.Y. Wang and S.D. Tanksley: Polymorphism and phylogenetic relationships among species in the genus Oryza as determined by analysis of nuclear RFLPs. Theor. Appl. Genet., 83, 565-581 (1992).

6 ) Q. Zang, M.M.A. Saghai, T.Y. Lu and B.Z. Shen: Genetic diversity and differentiation of Indica and Japonica rice detected by RFLP analysis. Theor. Appl. Genet., 83, 495-459 (1992).

7 ) J.G. Williams, A.R. Kubelik, K.J. Livak, J.A. Rafalski and S. V. Tingey: DNA polymorphisms amplified by arbitrary primers are useful as genetic markers. Nucleic Acids Res., 18, 6531 -6535 (1990).

8 ) S. Fukuoka, K. Hosaka and O. Kamijima: Use of random amplified polymorphic DNAs for identification of rice accessions. Jpn. J. Genet., 67, 243-252 (1992). 
9 ) L-X. Yu and H.T. Nguyen: Genetic variation detected with RAPD markers among upland and lowland rice cultivars. Theor. Appl. Genet., 87, 668-672 (1994).

10) G. Wang, S. Castiglione, J. Zhang, R. Fu, J. Ma, W. Li, Y. Sun and F. Sala: Hybrid rice (Oryza sativa L.): identification and parentage determination by RAPD fingerprinting. Plant Cell Rep., 14, 112-115 (1994).

11) H.L. Ko, D.C. Cowan, R.J. Henry, G.C. Graham, A.B. Blakeney and L.G. Lewin: Random amplified polymorphic DNA analysis of Australian rice (Oryza sativa L.) varieties. Euphytica, 80, 179-189 (1994).

12) D.J. Mackill: Classifying Japonica rice cultivars with RAPD markers. Crop Sci., 35, 889-894 (1995).

13) T. Ishii, T. Nakano, H. Maeda and O. Kamijima: Phylogenetic relationships in A-genom species of rice as revealed by RAPD analysis. Genes Genet. Syst., 71, 195-201 (1996).

14) D. Cao and J.H. Oard: Pedigree and RAPD-based DNA analysis of commercial U.S. Rice cultivars. Crop Sci., 37, 16301635 (1997).

15) K.S. Wu and S.D. Tanksley: Abundance, polymorphism and genetic mapping of microsatellites in rice. Mol. Gen. Genet., 241, 225-235 (1993).

16) X. Zhao and G. Kochert: Phylogenetic distribution and genetic mapping of a (GGC) microsatellites from rice (Oryza sativa L.). Plant Mol. Biol., 21, 607-614 (1993).

17) G.P. Yang, M.A. Maroof, C.G. Xu and Q. Zhang: Biyashev, R.M. Comparative analysis of microsattelite DNA polymorphism in landraces and cultivars of rice. Mol. Gen. Genet., 245, 187-194 (1994).

18) A.P. Davierwala, K.V. Chowdari, S. Kumar, A.P.K. Reddy, P. K. Ranjekar and V.S. Gupta: Use of three different marker systems to estimate genetic diversity of Indian elite rice varieties. Genetica, 108, 269-284 (2000).

19) H.F.J. Bligh, N.W. Blackhall, K.J. Edwards and A.M. McClung: Using amplified fragment length polymorphisms and simple sequence length polymorphisms to identify cultivars of brown and white milled rice. Crop Sci., 39, 1715-1721 (1999).

20) N.S. Bautista, R. Solis, O. Kamijima and T. Ishii: RAPD, RFLP and SSLP analyses of phylogenetic relationships between cultivated and wild species of rice. Genes Genet. Syst., 76, 71-79 (2001).

21) G.Q. Yu, Y. Bao, C.H. Shi., C.Q. Dong and S. Ge: Genetic diversity and population differentiation of Liaoning weedy rice detected by RAPD and SSR markers. Biochem. Genet., 43, 261-270 (2005).

22) Y.J. Shen, H. Jiang, J.P. Jin, Z.B. Zhang, B. Xi, Y.Y. He, G. Wang, C. Wang, L. Qian, X. Li, Q.B. Yu, H.J. Liu, D.H. Chen, J.H. Gao, H. Huang, T.L. Shi and Z.N. Yang: Development of genome-wide DNA polymorphism database for mapbased cloning of rice genes. Plant Physiol., 135, 1198-1205 (2004).

23) K. Shirasawa, L. Monna, S. Kishitani and T. Nishio: Single nucleotide polymorphisms in randomly selected genes among japonica rice (Oryza sativa L.) varieties identified by PCRRF-SSCP. DNA Res., 11, 275-283 (2004).

24) K. Ohtsubo, T. Fujii, Y. Hashino, H. Toyoshima, H. Okadome, S. Nakamura and S. Kawasaki: Cultivar identification of domestic milled rice by RAPD method. Nippon Shokuhin Kagaku Kogaku Kaishi, 44, 386-390 (1997) (in Japanese).

25) K. Ohtsubo, S. Nakamura, H. Morooka, T. Fujii, T. Fuse and S. Kawasaki: Identification of domestic rice cultivars by RAPD method using a single grain of cooked rice as a sample. Nippon Shokuhin Kagaku Kogaku Kaishi, 46, 262-267 (1999) (in Japanese).

26) K. Ohtsubo, S. Nakamura, K. Yoza and K. Shishido: Identification of glutinous rice cultivars using rice cake as samples by the PCR method. Nippon Shokuhin Kagaku Kogaku Kaishi, 48, 306-310 (2001) (in Japanese).

27) K. Ohtsubo, S. Nakamura and T. Imamura: Development of the primer sets for identification of the cultivar, Koshihikari, by PCR. Nippon Nogeikagaku Kaishi, 76, 388-397 (2002) (in Japanese).

28) S. Nakamura, H. Okadome, K. Yoza, K. Haraguchi, T. Oku- nishi, K. Suzuki, H. Satoh and K. Ohtsubo: Differentiation and search for palatability-factors of world-wide rice grains by PCR method. Nippon Nogerikagaku Kaishi, 78, 764-779 (2004) (in Japanese).

29) B.O. Juliano: A simplified assay for milled-rice amylose. Cereal Sci. Today, 16, 334-340, 360 (1971).

30) AOAC Official method. 920.87 Protein (Total) in Flour, Final action (1995).

31) H. Okadome, H. Toyoshima and K. Ohtsubo: Multiple measurements of physical properties of individual cooked rice grains with a single apparatus. Cereal Chem., 76, 855-860 (1999).

32) S.O. Rogers and A.J. Bendich: Extraction of DNA from plant tissues. in Plant Molecular Biology Manual A6, Kluwer Academic Publishers, Dordrecht, Belgium, pp. 1-10 (1988).

33) C.N. Stewart and L.E. Via: A rapid CTAB DNA isolation technique useful for RAPD fingerprinting and other PCR application. Biotechniques, 14, 748-750 (1993).

34) K. Ohtsubo, H. Toyoshima and H. Okadome: Quality assay of rice using traditional and novel tools. Cereal Foods World, 43, 203-206 (1998).

35) C.J. Bergman, K.R. Bhattacharya and K. Ohtsubo: Rice enduse quality analysis. in Rice, E.T. Champagne, ed., 3rd Ed., Americ. Assoc. Cereal Chem, St Paul, MN, USA, pp. 415-472 (2004).

36) J.T. Summerton and A.R. Bestwick: A rapid method for preparation of bacterial plasmids. Anal Biochem., 133, 79-84 (1983).

37) H. Yanase, K. Ohtsubo and K. Hashimoto: Studies on quality and processing suitability of glutinous rice. Rep. Nat. Food Res. Inst., No. 45, 1-8 (1984) (in Japanese with an English summary).

\section{PCR 法による米 (Oryza sativa L.) の品種判別および その米加工品への応用}

$$
\text { 大坪研一 }{ }^{1} \text {, 中村澄子 }{ }^{1}
$$

\section{1独農業・食品産業技術総合研究機構食品総合研究所}

$$
\text { (305-8642 つくば市観音台 2-1-12) }
$$

米 (Oryza sativa L.) の品種は, 食味, 加工適性, 価格等 に影響するので，その判別技術の開発が必要とされてい る。筆者らは, 米粒から鋳型 DNA を抽出・精製する方法 および適正な STS プライマーを開発することにより, PCR 法による米の DNA 品種判別を可能にした。 マルチプ レックスプライマーセットは各国の広範な米の効率的な 判別に有用であることを示し， 2 種類のコシヒカリ判別用 セットを開発した。また，米飯等の米加工品からの PCR

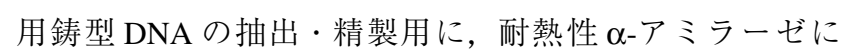
よる $80^{\circ} \mathrm{C}$ 処理, 次に SDS 共存下でのプロテイナーゼ $\mathrm{K}$ 処理と PCI 精製処理を行う「酵素法」を開発した。これ により，米飯 1 粒や餅などを試料とする原料米の DNA 品 種判別が可能になった。 